\title{
Rural Transformation in Various Ecosystem in Indonesia
}

\author{
Sri Hery Susilowati ${ }^{1, *}$, Ashari ${ }^{1}$, and Tahlim Sudaryanto ${ }^{1}$ \\ Indonesian Center for Agricultural Socio Economic and Policy Studies Jl. Tentara Pelajar No. 3B \\ Cimanggu Bogor West Java, Indonesia 16161
}

\begin{abstract}
The agricultural and rural sectors in Indonesia have experienced a dynamic transformation. This process of transformation reflected the changes in employment and income structure. This paper analyzes the changes in employment, income structures, and dietary patterns in various ecosystems, namely wetland paddy, dry land secondary, vegetables, and plantation. We use micro panel data collected from 1,155 rural households in 8 provinces, and 33 villages in Java and off-Java in 2007-2012 and 2016 -2018. The results showed that the share of agriculture employment decreased from $89.1 \%$ in 2007 to $56.7 \%$ in 2016 in the wetland paddy ecosystem, and the reverse was true for non-agricultural employment. Household income from agriculture was still dominant but showed a decreasing trend. The share of agriculture income declined; the most significant decline is in the wetland paddy ecosystem. Furthermore, a nonfarm income also tends to increase. Share of cereal consumption expenditure tends to decrease while processed foods and instant drinks tend to grow. For accelerating agricultural and rural transformation, government policy should focus on investment in rural infrastructure, promote labor and land markets, and build capacity building based on the need for a different ecosystem of the rural population.
\end{abstract}

\section{Introduction}

\subsection{Background}

The purpose of agricultural development is to improve farmers' and rural communities' quality of life, improve food security, and generate sufficient income for farmers $[1,2]$. Agricultural development policies influence the structure of rural and farmer's household economy. These changes can be analyzed from various aspects, including changes in employment, income, food system, diet change, poverty reduction, farm technology, and other elements that have important implications for the process of agricultural and rural transformation $[3,4]$. The changes in a rural economic structure reflect the process of agricultural and rural transformation. A rural transformation process can be seen in some countries, from changes in revenue sources [5]. The role of non- agricultural income in

\footnotetext{
* Corresponding author: srihery@gmail.com
} 
agricultural household income is getting higher, and most households have more than a single occupation.

The agricultural and rural sectors in Asian countries, including Indonesia, have experienced a dynamic transformation [6]. In this regard, the transformation is defined as follows: " A process of the complete societal change whereby reviews their rural societies diversify, reviews their economies and reduce reliance on agriculture; become dependent on distant places to trade and to acquire goods, services, and ideas; move from dispersed villages to towns and small and medium cities, and become culturally more similar to large groups of agglomerations " [7].

The reflection of this transformation is varied across countries and depends on the type of agricultural system, namely cereal-based agriculture, pasture land, fishery, forestry, and cereal + livestock-based agriculture [8]. Similar to some other countries in Asia, Indonesian Agriculture is dominated by a cereal-based farming system. Therefore, the transformation direction is from subsistence agriculture with cereal production toward high-value commodities, which are more commercialized and more off-farm activities [6].

The process of this transformation can be seen in the structure of agricultural production. The percentage of planted areas of high-value crops in Asia was tended to increase [3]. Likewise, the proportion of livestock value was also increasing, whereas crop production's value tended to decline [6]. From 1980 to 2010, the percentage of non- cereal planted areas has risen so fast, particularly in China, Indonesia, Lao, and Vietnam. In the subsequent phases, the direction of the transformation will move forward to the non-farm sector. This pattern will vary across countries and regions in the country $[3,6]$. Table 1 summarized the stages and paths of the transformation.

In addition to direction, another critical dimension of agriculture and rural transformation is its speed. As an impact of this transformation, labor productivity and household income are expected to increase, whereas the poverty level is supposed to decline. The success of change will be reflected in the degree of inclusiveness of this process. Countries that experienced fast transformation will experience rapid poverty rate reduction as well. Other dimensions are the inclusive nature of the transformation of the impact of gender and the marginalized community. Lastly, the change's success is also reflected in the achievements of food security and sustainable development.

Table 1. Direction and stages of agriculture and rural transformation in Asia

\begin{tabular}{|c|c|c|}
\hline Stage & Path of transformation & Institution, Policies and Investment \\
\hline 1 & Staple food production & $\begin{array}{c}\text { Institutions (e.g. land transfer markets) }+ \\
\text { infrastructure + new technology in staple } \\
\text { food production plus extensions) }\end{array}$ \\
\hline 2 & Agricultural diversification & $\begin{array}{c}\text { Market reform + investments on irrigation / road } \\
\text { infrastructure }\end{array}$ \\
\hline 3.1 & Farming + part time non-farm & Local SME policy in rural areas \\
\hline 3.2 & $\begin{array}{c}\text { Increasing specialization on } \\
\text { farm or non-farm jobs }\end{array}$ & $\begin{array}{c}\text { Development of labor and land rental } \\
\text { markets }\end{array}$ \\
\hline 3.3 & $\begin{array}{c}\text { Agric Mechanization and more } \\
\text { off-farm job }\end{array}$ & $\begin{array}{c}\text { Process associated with land consolidation, } \\
\text { mechanization, urbanization, etc. }\end{array}$ \\
\hline 4 & $\begin{array}{c}\text { Integrated urban-rural and } \\
\text { sustainable development }\end{array}$ & $\begin{array}{c}\text { Effort to eliminate rural-urban gap and build } \\
\text { sustainable rural development }\end{array}$ \\
\hline
\end{tabular}

Source: [6] 
The success of the transformation will vary across countries and the regions in the country [9]. In South Asia, the process is still in the early stage, where in addition to the farm, there is also non-farm employment on a part-time basis. In the Southeast Asia region, the process is considered in the middle stage, characterized by increasing specialization in both farm and nonfarm sectors [3]. A much more advanced stage of this transformation is observed in China, where agricultural mechanization and non-farm employment are dominated by the rural economy, at least in some regions $[3,10]$.

Many factors affect the transformation process's level of success, such as resource endowment, public policy shifting, socio-cultural settings, and institutional innovation $[3,11]$. Besides, amenable factors are also determinant of success, such as technology innovation, investment, institutions (in particular, those related to land and labor), and government policies [2]. In pursuit of promoting the success of the transformation, public policy is the role of prioritizing investment, institutional development, and a set of incentive policies.

The impact of sustainable agricultural development leads to agricultural and rural transformation. From the national point of view, the transformation is characterized by changes in the dominance of commodities planted, labor and income structure, and household consumption patterns. The data and information available regarding the rural transformation process so far is only at the macro level. In contrast, the impact of agricultural development on rural transformation varies according to different ecosystems. There has been no study to analyze the rural transformation through structural changes of rural household income, occupation, and consumption at the diverse ecosystems. Information on rural transformation at different ecosystem locations is necessary for formulating location-specific agriculture and rural policies. This research aims to analyse the performance of the rural transformation through structural changes of rural household income, occupation, and consumption at the different ecosystems

\section{Research Method}

The data used is the 'PATANAS' database of ICASEPS (the Indonesian Center for Agriculture Socio Economic and Policy Studies), Indonesian Ministry of Agriculture. The micro panel survey was conducted at eight provinces, namely: Central Java, East Java, West Java, North Sumatera, Jambi, Lampung, West Kalimantan, and South Sulawesi. The total number of sample villages are 33 villages. The study's location was chosen based on different ecosystems (the type of land and the dominant commodity planted). The sample villages are grouped into four ecosystems, namely (1) irrigated land with the primary commodity of paddy (14 villages); (2) dry land with secondary crops of corn, soybean, cassava, peanut (7 villages); (3) dry land with the main commodity of vegetables (4 villages); (4) dry land with the main commodity of estate crops (8 villages). A survey at paddy- irrigated ecosystems was conducted in 2007 and 2016; secondary and vegetable crops-dry land ecosystems were in 2008 and 2017, and plantation-dry land ecosystems were in 2009 and 2018.

The sample households were rural household, selected using the stratified random sampling method based on the household sampling frame using two strata, namely: (1) the land holding, and (2) the primary source of household income. The number of sample households in each village is around 40 households, consisting of (a) farmer owner/tenant households, (b) nonfarm business households, (c) farm laborers households, and (d) nonagricultural workers, professionals, and others. With the four different groups of the household sample, it is expected that the sample households will be able to represent the overall rural population livelihoods. The total number of sample households is 1.155 households. The survey data were processed and analyzed descriptively. 


\section{Result and Discussion}

Rural transformation shows the process whereby the economic, social, and cultural differences between rural and urban gradually become vague and mutually complementary to each other. The concept refers to changes in rural areas' characteristics, which were initially characterized by agriculture economic base oriented towards non-agriculture [7]. Four crucial processes associated with the transformation of rural areas [12], namely : (a) Agriculture system directly and indirectly more involve producers in the marketing of agricultural products, so that rural agricultural producers depend on the global dynamics, (b) Rural economy become more diversified to various types of rural non-farm occupations, (c) Concerning to point (b), the migration of domestic and transnational have a contribution on rural livelihoods, (6) The small town center grow in the countryside as a market center and services for the rural economy

While [13] stated that sustained income growth for decades led to changes in the agricultural sector's economic structure. These changes include urbanization, rural non- agricultural economic growth, diet diversification, and revolution in the supply chain. This paper discusses the changes in livelihood, urbanization, income, and household consumption patterns for showing there has been a rural transformation from the agricultural sector to a non-agricultural. The process of rural transformation differs according to different ecosystems.

\subsection{Structural changes on household employment}

The labor force's structural changes from agriculture to non-agriculture theoretically be explained through the agriculture labor market framework, where farmer decisions to allocate time for leisure, farm work, and off-farm work are limited by time and budget availability[14]. Key elements in the agricultural labor market include the number of the labor force, the number of workers employed, the labor contribution in agriculture, and human capital quality. Other vital elements are wage level policies, frameworks, regulations, and employment policies, such as subsidies, taxes, insurance, employment contracts, work protection, and other policies related to the labor market $[14,15]$.

The study results show the agricultural transformation process over the last ten years, mainly related to changes in rural communities' livelihoods. Labor participation in agriculture and nonagriculture is calculated from the members' main occupations only. In general, they have other income sources besides the primary income, both in agriculture and non-agriculture. The contribution of the non-agricultural sector in rural employment is increasing, but in general, the agriculture sector remains dominant, and the share of agriculture employment varies by an ecosystem.

Table 2 shows the change in the percentage of the labor force employed in agriculture and non- agricultural sectors during the analysis period. The rate of change varies according to the ecosystem. The most significant contribution to absorbing the non- agricultural employment is in the paddy ecosystem, which increased from 11 percent to 43 percent in the 2007-2016 period. The contribution of the secondary crops - the dryland ecosystem is the second biggest. Meanwhile, the vegetable and estate crop dryland ecosystem's contribution to absorbing nonagricultural labor is relatively lower than in other ecosystems. The difference contribution of the non-agricultural sector in absorbing rural employment is related to whether farming can meet the family's financial need. If farming income is sufficient for family needs, households do not need to find other income sources or diversify jobs in non-agriculture. Diversification into nonagricultural jobs is also related to the accessibility of rural areas to cities, the level of education of farmers, rural-urban incentive differences, and other factors relating to farmers' decisions to migrate to the cities to find non-agriculture jobs. 
Table 2. The changes in agriculture contribution to employment

\begin{tabular}{|l|c|c|}
\hline Ecosystem / Sector & \multicolumn{2}{|c|}{ Year / Employment contribution (\%) } \\
\hline Wetland rice & $\mathbf{2 0 0 7}$ & $\mathbf{2 0 1 6}$ \\
\hline Agriculture (\%) & 89.08 & 56.69 \\
\hline Non - agriculture (\%) & 10.92 & 43.31 \\
\hline Dry-land secondary crop & $\mathbf{2 0 0 8}$ & $\mathbf{2 0 1 7}$ \\
\hline Agriculture (\%) & 78.58 & 61.15 \\
\hline Non - agriculture (\%) & 21.42 & 38.85 \\
\hline Dry-land vegetable crop & $\mathbf{2 0 0 8}$ & $\mathbf{2 0 1 7}$ \\
\hline Agriculture (\%) & 84.54 & 77.78 \\
\hline Non - agriculture (\%) & 15.46 & 22.22 \\
\hline Dry-land estate crop & $\mathbf{2 0 0 9}$ & $\mathbf{2 0 1 8}$ \\
\hline Agriculture (\%) & 77.99 & 69.86 \\
\hline Non - agriculture (\%) & 22.01 & 30.14 \\
\hline Source primry (pros &
\end{tabular}

Source: primary data (processed)

In vegetable and estate crops ecosystems, farming income is relatively high, so there is little incentive to diversify employment to non-agriculture. Diversification to non-agriculture occupation in those ecosystems is also not supported by the accessibility of rural-city transportation. In contrast to the ecosystem of wetland paddy and secondary crops dry land, farming income is not as high as in the estate crops and vegetable ecosystem. Furthermore, rural transportation accessibility to the city is relatively easier, encouraging labor to find an alternative job in the non-farm sector. In general, having greater access to urban employment opportunities increased the likelihood of off-farm work [16].

Base on the case of the four ecosystems, in general, the agriculture sector is still the main occupation for most of rural households ( $57-78$ percent). Over the last ten years, there has been an increase of non- agricultural sector contribution in absorbing rural labor. The irrigated land ecosystem has the most significant contribution in absorbing rural non-agricultural labor force [17] .

The decrease of agricultural labor, if followed by an increase in the household agricultural income, will increase agriculture labor productivity. On the national level, the growth of agricultural value-added per Indonesian labor force during the 2000-2011 period was 3.2 percent per year, increased from the 1990-1999 period of 0.9 percent per year. The growth of agricultural value-added per Indonesian worker is higher than in some Southeast Asian countries, namely Lao PDR, the Philippines, Vietnam, Thailand, but still lower than Malaysia and Cambodia [18]. Analysis using the same data, shows some factors affecting households looking for another job than farming work [19]. These factors are age, working female household members, agriculture land occupation, and household assets. Younger family heads tend to diversify their work into agriculture and non-agriculture. Households with a higher number of working female also tend to diversify into non-agricultural work. The higher the household assets tends to expand into non - agricultural activities. Similarly, household decisions to have multi-job both in agriculture and non-agriculture also influenced by the size of landholding. The land holding determines whether households will remain in farming or diversify into non-agricultural activities [5].

Movement of agricultural labor to non-agriculture is a consequence of the transformation process. Reduce the intake of agricultural labor is expected to increase agricultural productivity. However, suppose the agrarian laborers in a rural area are old laborers with low productivity. In that case, transforming agriculture into non-agriculture in rural areas will decrease agricultural productivity in rural areas as a whole. 


\subsection{Urbanization Participation}

The labor force migration mostly aims to find jobs mainly in the cities. Villages with high level of urbanization; urbanization leads to disrupt the fulfillment of farming labor and the increase of nationwide food needs. In more cases, most young farmers are not willing to work on the farm and more interested in working as industrial workers in urban areas. Simultaneously, agricultural mechanization, especially by large- scale farmers, and the shift of family farmers to corporate farmers, resulted in lower human labor demand. A further impact is that farm employment opportunities in the village are also declining, encouraging workers to do urbanization. However, if the migrant workers have no skill and education to meet the city's labor needs, urbanization will only be burden on the town. On the other hand, the lack of farm employment in rural areas due to urbanization will disturb the food production process and food security. The link between urbanization, rural transformation, and food security, in particular, is how the rural areas transformed to meet the food need of urban area [20].

Table 3 shows that urbanization activities have increased in most ecosystems, except that in the dry land-secondary crops ecosystem decreasing. In the dry land estate crop ecosystem, urbanization actors are mostly women workers who work as clerks, domestic workers, factory workers, or company employees. The increase of industrial and services sectors, lead to an increased in the level of urbanization. In the context of people's movement out of the village to work, migration to urban areas and intra-villages in rural areas, when non-agricultural activities in the rural area are developed [13].

Most of the destination location of urbanization is the center of the district or province. In terms of transnational labor migration, Malaysia, Singapore, Hong Kong, Saudi Arabia, and a small portion of Papua New Guinea are the dominant destination. Urbanization employment is predominantly under 40 years of age. It means that the absorption of non-agricultural work in urban areas prioritizes young and productive employment, mostly with a secondary level of education.

Table 3. Urbanization by household members

\begin{tabular}{|l|c|c|}
\hline Ecosystem & \multicolumn{2}{|c|}{ Year / Urbanization participation (\%) } \\
\hline Wetland rice & $\mathbf{2 0 0 7}$ & $\mathbf{2 0 1 6}$ \\
\hline & na & 36.09 \\
\hline Dry-land secondary crop & $\mathbf{2 0 0 8}$ & $\mathbf{2 0 1 7}$ \\
\hline & 41.74 & 35.68 \\
\hline Dry-land vegetable crop & $\mathbf{2 0 0 8}$ & $\mathbf{2 0 1 7}$ \\
\hline & 15.70 & 29.75 \\
\hline Dry-land estate crop & $\mathbf{2 0 0 9}$ & $\mathbf{2 0 1 8}$ \\
\hline & 26.43 & 42.68 \\
\hline
\end{tabular}

Source: primary data (processed)

The trend of agricultural employment, as described above, strengthen the phenomenon of young rural workers not to choose agriculture as their primary occupation. They tend to go to cities to find jobs in the non-agricultural sector. Young workers' decision to work in cities is mainly due to the driving factors, including agricultural land occupation, which is getting smaller and not economic. From the economic point of view, the young rural labor market looking for non-agriculture jobs is rational since the agricultural sector is insufficient financial needs [21].

Two factors generally cause urbanization, i.e., push factors and pull factors. The push factor is mainly limited resources, primarily agricultural land and other productive assets, and employment opportunities. For young workers who migrate to cities, the agriculture sector is less prestigious, dirty, and risky. Also there is a mismatch between the quality of education and job 
opportunities in the village. Concerning education, the research using data from the UN World Urbanization Prospect, indicated that education level is a very significant factor affecting urbanization [22]. The higher the level of education, the workforce will tend to move to the city to find work.

Meanwhile, the pull factor of urbanization is the difference of incentives received by workers in agriculture in rural versus non-agricultural urban areas. As a development center that offers better opportunities, the city is an attraction for young workers as destination of urbanization. The factors are generally supported by connectivity, information, and networking to non-agricultural work.

Urbanization cannot be eliminated as long as there are productivity gaps between sectors and inequality of growth and development between regions. The level of industrialization of the city also has a significant determinant of urbanization. Towns/countries with high industrialization levels will create employment opportunities for higher levels of education, and in turn, will attract workers to the city, and at the same time will increase the return to education [22].

Another analysis of the survey data derives the conclusion that rural employment in the last ten years who work and looking for a job in the city is increasing [23]. Most of them are tended to work or do business in the non-agricultural sector, both in the formal and non-formal sectors. The trend of increasing rural youth workers working in the non-agricultural sector in urban areas happens in rural areas near urban areas and for young workers in rural areas located relatively far from urban areas.

\subsection{Structural Change on Household Income}

The rural household income structure is still dominated by the agricultural sector with a decreasing trend, except in the dry land for vegetables and secondary crops. The share of agricultural income is more than 50 percent (around 50-75 percent), except in secondary crops dry land, the percentage is less than 50 percent. The increase in agricultural income in the vegetable dry-land ecosystem is due to rising chili prices in 2017. In contrast, the activities of non - farm for the last ten years tend to increase in the irrigated land ecosystem and dry land estates crop ecosystem. Meanwhile, on dry land, vegetables tend to decrease, and in the dry land, secondary crops are relatively stable. The non-agricultural income contributes to the farmer's income is quite large, around 46 percent for paddy land ecosystem, dry-land secondary crops ecosystem around 53 percent, vegetable dry land around 17 percent, and dry land estate crop ecosystem around 39 percent (Table 4).

Real household income (as a deflator is the national average dried paddy price) increases in the dry land secondary crops ecosystem, estate crops, and vegetables, while in the wetland land paddy ecosystem slightly decreases. Within about ten years, the increase in real household income in the vegetable dry-land ecosystem was relatively high, namely by 197 percent, in the dry-land secondary crops ecosystem by 101 percent. A modest increase in real income occurred in the estate crops dry-land ecosystem by 37 percent because, at the time of the analysis (in 2018), prices for oil palm, rubber, cocoa, and sugar cane were decline. While in the wetland paddy ecosystem, household income slightly decreases by about 12 percent. In last year's observation, the average household real income in the vegetables dry-land ecosystems is 15, 25 tons dried paddy/year (100 percent), and in estate crops dry-land 63 percent. Meanwhile, the wet-land paddy ecosystem is 59 percent, and dry-land secondary crops are 42 percent.

Shifting the share of agriculture to non-agricultural income is in line with increasing agricultural sources' diversification to non-agriculture income. Non-farm income sources provide a higher percentage of household income than the other non-agricultural sources of income, namely income as an employee / professional (accounts for about 10-15\%). The dominant share of income as professional staff/employee in line with the shift of labor from 
agriculture to non-agriculture and urbanization by young workers from villages to cities.

The increase of non-agriculture activities and services, a rural household income source, is a part of the rural and agricultural transformation process [24]. In most countries, the share of agricultural income is less than 50 percent. The rural non-farm sector has an essential role in reducing or mitigating income risk and diversification strategy. It is especially true for small or no landholding farmer households. With limited resources (low education and skills), limited capital, and inadequate social levels, poor households' diversification in non-agricultural activities tends to be less profitable.

Table 4. The changes of agricultural income contribution

\begin{tabular}{|c|c|c|c|c|}
\hline \multicolumn{5}{|c|}{ Income } \\
\hline $\begin{array}{l}\text { Ecosystem / } \\
\text { Year }\end{array}$ & Agriculture (\%) & \begin{tabular}{|c|} 
Non- \\
agriculture (\%)
\end{tabular} & $\begin{array}{c}\text { Total income } \\
\text { (IDR } \\
\text { million) }\end{array}$ & $\begin{array}{c}\text { Real income (dried } \\
\text { paddy- } \\
\text { ton) }\end{array}$ \\
\hline \multicolumn{5}{|c|}{ Wetland rice } \\
\hline 2007 & 67.08 & 32.92 & 27.12 & $10: 23$ \\
\hline 2016 & 53.94 & 46.06 & 49.29 & 9.04 \\
\hline \multicolumn{5}{|c|}{ Dry-land secondary crop } \\
\hline 2008 & 46.78 & 53.22 & 8.88 & 3.16 \\
\hline 2017 & 47.24 & 52.76 & 35.08 & 6.37 \\
\hline \multicolumn{5}{|c|}{ Dry-land vegetable crop } \\
\hline 2008 & 76.35 & 23.65 & 14.41 & 5,13 \\
\hline 2017 & 82.75 & 17.25 & 84.05 & 15.25 \\
\hline \multicolumn{5}{|c|}{ Dry-land estate crop } \\
\hline 2009 & 68.90 & 31.10 & 20.95 & 7.02 \\
\hline 2018 & 61.02 & 38.98 & 52.62 & 9.59 \\
\hline
\end{tabular}

Source: Primary data (processed)

\subsection{The changes in diet pattern}

Engel's Law proposed, increasing per capita income consumer spending for non-food increases faster than consumer spending for food. The share of food expenditure to total household expenditure in the four ecosystems in the last year is still larger than that of non- food expenditures, ranging from 60.3 percent (in dry-land estate crops ecosystem) to 61.7 percent (in dry-land secondary crops ecosystem). The share of food expenditure tends to increase during the last ten years, but the increase is relatively small. The increase in the percentage of food expenditure is contrary to Engel's Law. This condition occurs due to the rise in income is followed by a faster increase in food expenditure. Food expenditure increases faster because changes in food consumption patterns and styles consume high-quality food, which is more expensive. The openness of the region and the development of restaurants and culinary industries in the township of the sub-district or village that serve food and drinks make it easier for the public to get ready-to-serve food more expensive than food to process on their own. Similarly, instant beverage/soft drink and mineral water consumption tend to increase, although its share is relatively small (Table 5).

The share of consumption expenditure tends to decrease for cereal as conventional food is obtained by cooking them self unless processed foods and beverages instantly increase. However, the share of expenditure on cereals remained dominant. The decline in the share of cereals' expenditure occurs mainly in the paddy ecosystems, dry land secondary crops, and dry land vegetable crops ecosystem, where the village is more open and closer to the sub-district 
center. In dry-land ecosystems far from the center of the city, the increase in food expenditure for processed food and instant drinks is smaller. According to [15], rural transformation in the Asia Pacific Region (APR) is characterized by changes in food consumption patterns from flour and rice groups to fruits and vegetables, meat and dairy products, fish, sugar, and oil increasing income and urbanization.

Table 5. The changes on share of household expenditure for cereal, processed food and instant drinks

\begin{tabular}{|l|c|c|c|}
\hline & \multicolumn{3}{|c|}{ Percentage to total HH expenditure (\%) } \\
\hline Ecosystem / Year & Cereal & Processed food & \multicolumn{2}{|c|}{ Instant Drink } \\
\hline Wetland rice & & & 2.31 \\
\hline 2007 & 13.97 & 3.06 & 2.51 \\
\hline 2016 & 11.87 & 5.63 & \\
\hline $\begin{array}{l}\text { Dry-land secondary } \\
\text { crop }\end{array}$ & & & 1.22 \\
\hline 2008 & 15.23 & 2.64 & 2.59 \\
\hline 2017 & 14.13 & 2.90 & \\
\hline $\begin{array}{l}\text { Dry-land vegetable } \\
\text { crop }\end{array}$ & & & 0.74 \\
\hline 2008 & 14.08 & 3.02 & 1.86 \\
\hline 2017 & 12.53 & 4.65 & \\
\hline Dry-land estate crop & & & 2.88 \\
\hline 2009 & 13.74 & 5.71 & 2.75 \\
\hline 2018 & 13.69 & 4.08 & \\
\hline
\end{tabular}

Source: primary data (processed)

\section{Conclusion and policy implication}

Agriculture activities are still a principal occupation for rural households; however, the nonagricultural sector's role in absorbing labor increased in the last ten years. The most substantial share increase of the non-agricultural industry to absorb rural employment is in the irrigated paddy land ecosystem. Urbanization also increases in all ecosystems except in the dryland secondary crops ecosystem.

Real household income in the secondary dryland crops, estate crops, and vegetable crops ecosystem increased, except in the wetland paddy ecosystem. The rural household income structure is still dominated by the agricultural sector with a declining trend, except in dryland vegetables and secondary crops ecosystem. Conversely, non-agricultural activities over the last ten years have tended to increase for the ecosystem of irrigated paddy and dry land estate crops ecosystem. Meanwhile, the dryland vegetable ecosystem has tended to decline, and in dryland secondary crop ecosystem has remained relatively stable.

The share of food expenditure to total household expenditure is still higher than the percentage of non-food cost and tends to increase over the last ten years, but the increase is relatively small. The share of spending for cereal as conventional food tends to decrease, while processed food and instant beverages tend to increases; however, the share of expenditure on cereals is still dominant.

To accelerate agricultural and rural transformation, the government should focus on investment in rural infrastructure, promote labor and land markets, and facilitate capacity building based on the need for a different rural population ecosystem. Future research should focus on the direction, outcome, and driver of transformation in different rural economies to better understand the dynamic of agricultural and rural transformation. 
Acknowledgement. All authors contributed equally to this work. All authors discussed the results and implications and commented on the manuscript at all stages. We thank the Indonesian Center for Agricultural Socio-Economic and Polices Studies (ICASEPS), Indonesian Ministry of Agriculture, for permitting us to use the Patanas database for writing this script.

\section{References}

1. Udemezue JC, Osegbue EG. Ann Rev Resear 1, 5: 00134-00137 (2018).

2. IFAD. Rural Development Report 2016. https://www.ifad.org/documents/30600024/30604585/RDR_OVERVIEW_WEB.pdf/e8e9e9 86-2fd9-4ec4-8fe3-77e99af934c4

3. R. Vos. WIDER Working Paper 87 (2018). https://www.wider.unu.edu/sites/default/files/Publications/Working-paper/PDF/ wp201887.pdf

4. T. Reardon, D. Tschirley, M. Dolislager, J. Snyder, C. Hu, and S. White. Michigan State University and Global Center for Food Systems and Innovation. May 2014. http://www.fao.org/fileadmin/templates/ags/docs/MUFN/DOCUMENTS/MUS_Reardon_20 14.pdf

5. B. Davis, P. Winters, G. Carletto, K. Covarrubias, E. Quinones, A. Zezza, K. Stamoulis, G. Bonomi, D. Giuseppe. World Development 38, 1, 48-6 (2010).

6. J. Huang. World Food Policy 4, 2 / Spring (2018)

7. J. Berdegué, T. Rosada, and A. Bebbington. In Chapter 30 in B. Currie-Alder, R. Kanbur, D. Malone and R. Medhora (eds) Oxford University Press, Oxford (2014).

8. ACIAR. Research Proposal, Project NumberADP/2017/024. ACIAR, Canbera.(2018)

9. S. Boettiger, N. Denis, S. Sanghvi. McKinsey\&Company. Agriculture \& Chemicals November (2017). https://www.mckinsey.com/industries/chemicals/our-insights/readinessfor-agricultural-transformation

10. R. Briones and J. Felipe. Asian Development Bank Economics Working Paper Series No. 363 (2013). https://ssrn.com/abstract=2321525 or http://dx.doi.org/10.2139/ssrn. 2321525

11. J. Huang, J. Ding. Agricultural Economics 47, supplement: 227-237 (2016).

12. E. Lazaro, J. Agergaard, M.N Larsen, J. Makindara, T.B. Thomsen. European Journal of Development Research. 31,1:72-94 (2019)

13. T. Reardon, C.P. Timmer. Global Food Security 3, 2:1-10 (2014).

14. T. Donnellan, K. Hanrahan, T. Hennessy. Factor Markets Working paper 24 (2012). http://aei.pitt.edu/58536/1/Factor_Markets_24.pdf

15. B.Tocco, S. Davidona, A. Bailey. Working Paper. 20 (2012). https://econpapers.repec.org/paper/agsfamawp/122847.htm

16. S.J. Nantel, D. Freshwater, A. L. Katchova. Agricultural Finance Review 7, 3: 329-346 (2011).

17. F. Norfahmi, N. Kusnadi, R. Nurmalina, R.Winandi. Informatika Pertanian 26, 1: 13 - 22 (2017).

18. D. Dawe. ESA Working Paper No. 15-04. Food and Agriculture Organization of the United Nations. Rome. (2015)

19. S.H. Susilowati. J. Agro Ekon, 35. 2, 105-126 DOI: http://dx.doi.org/10.21082/jae.v35n2.2017.105-126 (2017) 
20. FAO. Global Forum on Food Security and Nutrition Summary of the online discussion no.

126. (2016). http://www.fao.org/3/a-bl630e.pdf.

21. S.H. Susilowati. Forum Penelit Agro Ekon., 34, 2, 103-123 (2016)

22. Hofmann, G. Wan. ADB Economics Working Paper Series. 355 July (2013).

23. Sumaryanto, Hermanto, M. Ariani, S.H. Suhartini, RD Yofa, D H. Azahari. Laporan Akhir Penelitian. Bogor (ID): Pusat Sosial Ekonomi dan Kebijakan Pertanian.(2015)

24. IFAD. A policy brief. Rome, IFAD (2014). https://www.ifad.org/documents/38714170-

/39135645/apr+policy.pdf/d01cf95d-49ba-4ffb-9ddc-e44c57cdca18 